\title{
Explant culture and multilineage differentiation of amniotic membrane derived stem cells
}

\author{
Özlem ÖZDEN AKKAYA ${ }^{1, a}$, Abu Salah Mohammad Golam KIBRIA ${ }^{1,2, b}$, Artay YAĞCI ${ }^{3, c}$, \\ Metin ERDOĞAN ${ }^{4, d}$, Korhan ALTUNBAŞ ${ }^{1, e, \varpi}$
}

\begin{abstract}
${ }^{1}$ Afyon Kocatepe University, Faculty of Veterinary Medicine, Department of Histology and Embryology, Afyonkarahisar, Turkey; ${ }^{2}$ Chittagong Veterinary and Animal Sciences University, Faculty of Veterinary Medicine, Department of Anatomy and Histology, Chittagong, Bangladesh; ${ }^{3}$ Muğla Sitkı Koçman University/Milas, Faculty of Veterinary Medicine' Department of Histology and Embryology, Muğla, Turkey; ${ }^{4}$ Afyon Kocatepe University, Faculty of Veterinary Medicine, Department of Veterinary Biology and Genetic, Afyonkarahisar, Turkey

aORCID: 0000-0001-6372-9155; ' $O$ ORCID: 0000-0003-1303-4341; ' ${ }^{\mathrm{O}}$ ORCID: 0000-0002-8081-9774; ${ }^{\mathrm{d} O R C I D: 0000-0003-0975-1989,}{ }^{\mathrm{e} O R C I D: 0000-0001-7580-3412}$
\end{abstract}

Corresponding author: korhana@aku.edu.tr

Received date: 24.11.2020 - Accepted date: 19.03.2021

\begin{abstract}
Amniotic membrane derived stem cells (AMSCs) are reported to have a comparatively higher potency than multipotent stem cells. These cells are shown to have low immunogenicity and no teratogenicity. Among various conventional methods of isolation using enzymes, explant culture method is believed to be an easy and cost-effective way to harvest stem cells. The purpose of this study was to isolate AMSCs from amniotic membrane of rats and to characterize them for multilineage differentiation, including generation of neurospheres to use them later in in-vivo experiments. Amniotic membranes were collected from Wistar rats on $17^{\text {th }}$ day of pregnancy. After processing of the tissues, AMSCs were isolated by the explant culture method and continued to grow until $10^{\text {th }}$ passage. The doubling time was estimated and the cells were analyzed for growth curve parameters at passages 5 and 9 . The osteogenic and adipogenic differentiation studies were carried out from the same cells after $3^{\text {rd }}$ passage. Neurospheres generation from AMSCs was performed using neurogenic induction media. The cells were further assessed for their mesenchymal, haemopoietic, and neurogenic marker expressions by immunofluorescence staining and PCR analysis The study suggests that AMSCs isolated through explant culture are reliable stem cells which could generate neurospheres under proper induction conditions and could be a potential candidate to be used on in-vivo neural degeneration models.
\end{abstract}

Keywords: Amniotic membrane, differentiation, explant culture, neurosphere.

\section{Eksplant kültür ve amniyotik membran kaynaklı kök hücrelerin çok yönlü farklılaşması}

Özet: Amniyotik membran kaynaklı kök hücrelerin (AMKH) multipotent kök hücrelere göre daha yüksek potansiyele sahip hücreler olduğu bildirilmiştir. Bu hücreler düşük immunojeniteye sahiptir ve teratojenik etkileri yoktur. Enzimatik yöntemlere dayanan çeşitli konvansiyonel metodların yanında eksplant kültür metodu, kök hücrelerin elde edilmesinde kolay ve ekonomik bir yöntem olarak görülmektedir. Çalışmada sıçan amniyotik membranından AMKH'lerin izole edilmesi ve daha sonra in vivo çalışmalarda kullanmak adına yapılan nörosfer farklılaştırması da dahil olmak üzere çoklu farklılaştırma çalışmaları ile hücrelerin karakterizasyonu amaçlandı. Amniyotik membranlar Wistar ırkı sıçanlardan gebeliklerinin 17. gününde toplandı. Bir takım işlemler sonrasında amniyotik membranlardan eksplant kültür metodu ile AMKH'ler izole edildi ve 10. pasaja kadar çoğaltıldı. Hücrelerin iki katına çıkma süreleri hesaplandı ve 5 ile 9. pasajlarda hücrelerin büyüme eğrisi parametreleri analiz edildi. Üçüncü pasajdan sonraki hücrelerde osteojenik ve adipojenik farklılaştırma çalışmaları yapıldı. AMKH'ler nörojenik indüksiyon medyumu ile nörosferlere farklılaştırıldı. Daha sonrasında hücreler mezenkimal, hemapoietik ve nörojenik belirteçlerin ifadesi bakımından immunositokimyasal boyama ve PCR analizi ile incelendi. Çalışma eksplant kültür ile izole edilen AMKH'lerin uygun koşullar altında nörosfer oluşturma kapasitesine sahip, güvenilir bir kök hücre kaynağı olduğunu ve in-vivo nöral dejenerasyon modellerinde kullanılabilecek yeni bir potansiyel aday olduğunu önermektedir.

Anahtar sözcükler: Amniyotik membran, eksplant kültür, farklılaştırma, nörosfer. 


\section{Introduction}

Amniotic membrane derived stem cells (AMSC) stands between embryonic stem cells and adult stem cells since they have a better potential to differentiate into many different types of cells compared to adult stem cells. Moreover, there are no ethical problems in isolation of AMSCs as these are easy to obtain non-invasively at parturition and do not induce immunogenic rejection. These features of AMSCs make them a preferable source for stem cell therapy $(12,24,26,29,37)$.

The two methods, enzymatic dissociation and explant culture are used to obtain stem cells from amniotic membrane. There are certain advantages of explant culture over enzymatic dissociation method. In explant culture method, it is possible to obtain higher numbers of cells (15) which are also more homogenous in context of their morphologies (35). The proliferation rates (35) and the viability of the obtained cells (43) are both reported to be higher for explants culture when compared to the enzymatic dissociation method. It is thought that these disadvantages in enzymatic applications may be caused by a decrease in adhesion properties due to enzyme application and loss of enzymes in washing and filtration stages (15). Further to that, the explant culture is more economical, and the processing of the tissues takes place in a much shorter time (15).

Stem cells are known to have potential to differentiate into neural progenitor cell clusters called as neurospheres (25) when stimulated by high concentrations of basic fibroblast growth factor (bFGF) and epidermal growth factor (EGF) in culture conditions (6). A variety of stem cell types such as adipose tissue derived stem cells $(9,28)$, bone marrow derived stem cells (9), olfactory mucosa derived stem cells (1), as well as amniotic membrane derived stem cells (42) are reported to have the capability to generate neurospheres. The generated neurosphere precursor cells can differentiate into astrocytes, neurons and oligodendrocytes by culturing in a proper culture medium containing different growth factors depending upon the desired differentiation, (31). Neurosphere generating precursor cells might also be used to treat neurodegenerative diseases in animals and humans without differentiating them (14). The subset of rat AMSCs, also have been reported to express neuroectodermal (neurofilament-M), mesodermal (fibronectin), and endodermal (a-1 antitrypsin) genes (25). There are few studies on neurosphere generation from human AMSCs $(3,42,44)$, however, authors failed to find any report on neurosphere generation from rat AMSCs. Invivo experimental studies about neurological disorders are being performed on experimental animals especially on rat (40), mouse (38) and rabbit (21). Therefore, it is important to obtain AMSCs derived neurospheres from experimental animals to learn the role of AMSCs derived neurospheres on neurological disorders and to use them in experimental models. In this study, we aimed to isolate the stem cells from the rat amniotic membrane by using explant culture method to show their proliferation potential and generate neurospheres from AMSCs.

\section{Materials and Methods}

Isolation of Amniotic Membrane Derived Stem Cells: All procedures were approved by the Ethical Committee of Afyon Kocatepe University, Turkey (AKÜHADYEK-29-16; 17.03.2016). The Wistar rats were obtained from the Experimental Animal Application and Research Center of Afyon Kocatepe University, Afyonkarahisar. The Wistar rats on the $17^{\text {th }}$ day of the pregnancy were anesthetized by intraperitoneal 21.1 $\mathrm{mg} / \mathrm{kg}$ ketamine and $4.2 \mathrm{mg} / \mathrm{kg}$ xylazine injections, and later euthanized with cervical dislocation to isolate amniotic membrane. Amniotic membrane pieces were seeded into 4 well plates. In each well, $500 \mu 1$ of Dulbecco's Modified Eagle's Medium (DMEM; Invitrogen, Carlsbad, CA) was added. The content of the culture medium was adapted from Nawaz et al. (2020) (27). The tissue explants were allowed to proliferate and generate cells for a week with renewal of culture media in every 48 hours (Figure $1 \mathrm{~A}, \mathrm{~B}$ ). After one week of culture, the adhered cells were detached from the surface by using $0.25 \%$ trypsin-EDTA (Gibco, USA) and seeded into T-25 cell culture flasks.
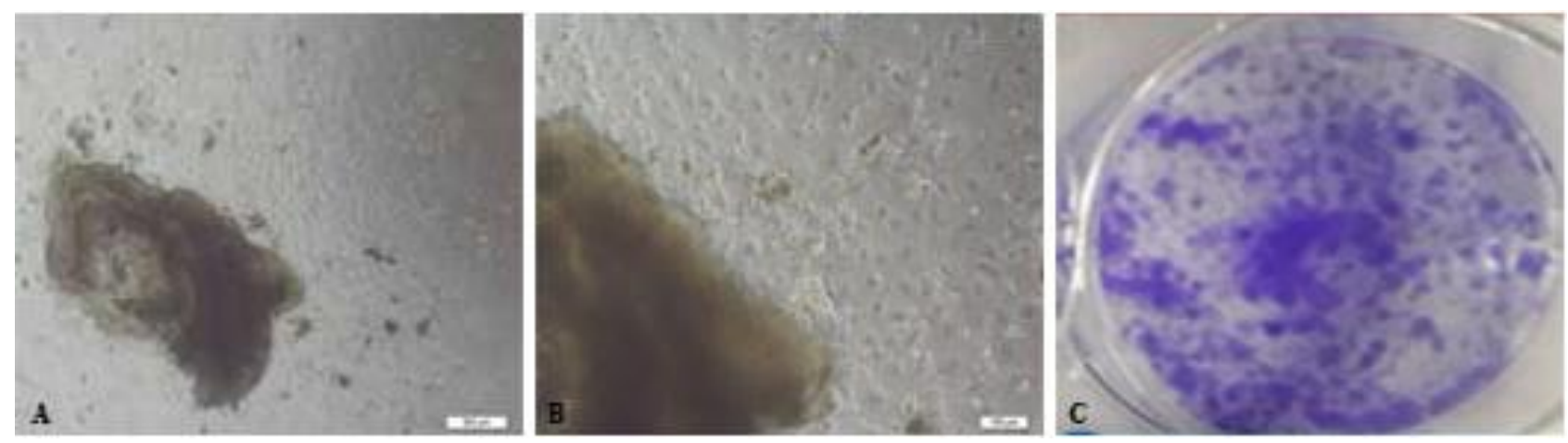

Figure 1. A, B: The cells were derived from the surroundings of the amniotic membrane tissues. C: Formed colonies of amniotic membrane derived stem cells. Crystal violet staining. Bar $=$ A:500 $\mu \mathrm{m}, \mathrm{B}: 100 \mu \mathrm{m}$. 
Colony Forming Unit: To observe the colonyforming capabilities, the cells from passage 1 were seeded in a 4-well plate at 1900 cells per well density. After 15 days, colony formation was confirmed by crystal violet (Premed, Turkey) staining (Figure 1).

Population Doubling Time and Growth Curve: The cells were cultured until $10^{\text {th }}$ passage for doubling time studies. The seeded and harvested cell numbers were recorded alongside culture durations for each passage. Population doubling time was calculated through the following formula (33).

$$
\operatorname{PDT}(\mathrm{h})=\frac{\text { Duration of culture }(\mathrm{h}) * \log (2)}{\log (\text { Final concentration }(\mathrm{M}) \text { of cell })-\log (\text { Initial concentration }(\mathrm{M}) \text { of cells })}
$$

Growth curve analysis was performed at P5 and P9. Briefly, cells were seeded in 4-well plates at $8 \times 10^{3}$ cells $/ \mathrm{cm}^{2}$ concentration. Culture media was changed every $3^{\text {rd }}$ day. Cells were trypsinized and counted at 2 days intervals.

PCR Analysis: Stem cell samples at P3 were collected in $1.5 \mathrm{ml}$ centrifuge tubes and immediately frozen in liquid nitrogen. The protocols specified by Nawaz et al. (2020) were used in the PCR analysis (27). PCR primers were designed by using FastPCR 6.0 (16) software. All primer base pairs, Tm values, and cDNA sizes of used genes are given in Table 1. Specific expressions of mesenchymal [CD44, CD105, ITGB1 (CD29), ALCAM (CD166)], neurogenic [Tubb3 (beta tubulin), Nestin, NCAM], and hematopoietic (CD34) genes were investigated by PCR analysis on undifferentiated cells.

Differentiation Studies: For differentiation studies and related staining, the protocols specified by the researchers $(27,28)$ were modified and applied. Cells in the third passage $\left(2.9 \times 10^{4} /\right.$ well) were used for adipogenic and osteogenic differentiation. One 4-well plate was used for each study. A well was spared as negative control for each type of differentiation which was cultured only with normal culture media and the remaining wells were used for differentiation experiments.
After 21 days, osteogenic differentiation was confirmed by alizarin red $\mathrm{S}$ staining and adipogenic differentiation was demonstrated by oil red $\mathrm{O}$ staining (27).

Neurosphere Generation and Immunofluorescence Staining: A previously utilized protocol was used for the neurospheres generation and immunofluorescence (IF) staining $(27,28)$ with a minor modification on doses of bFGF (R\&D Systems, USA) and EGF (R\&D Systems, USA) for neurospheres differentiation medium as 50 $\mathrm{ng} / \mathrm{ml}$ ratio was used for both growth factors. After 48 hours of incubation, sizes of the generated neurospheres were measured using Image $\mathbf{J}$ software (1.48 latest version:1.49e, pp-188, imagej.nih.gov/ij/). In order to confirm the differentiation, generated neurospheres were subjected to IF staining against Nestin (1:500, Mouse Monoclonal; Merck- MAB5326, Germany), ß-III Tubulin (1:200, Mouse monoclonal; Abcam- ab78078, UK), and Sox2 (1:50, Rabbit clonal; Merck- AB5603, Germany). For IF studies, cells were seeded into 4-well Millicell EZslide glasses (Merck, Ireland) at a concentration of $16 \times 10^{4}$ cells per well and cultured with serum-free neurosphere induction media for 48 hours with same conditions as described earlier. Neurospheres were photographed at $24^{\text {th }}$ and $48^{\text {th }}$ hours of induction. Cells were incubated with primary antibody solutions at $4{ }^{\circ} \mathrm{C}$ overnight in a humidity chamber. Anti-Nestin and anti- $\beta$ III Tubulin primary antibodies were subjected to goat antimouse Alexa Fluor 488 conjugated (1:250, Abcamab150117, UK), while anti-Sox2 primary antibody was subjected to goat anti-rabbit Alexa Fluor 488 conjugated (1:250, Abcam- ab150077, UK) after 1 hour of incubation with secondary antibodies, antibody solutions were rinsed by $1 \%$ Tween- 20 supplemented phosphate buffered saline (PBST) and one drop of DAPI Fluoroshield Mounting Medium (Abcam-ab104139, UK) was applied into wells for 1 minute. Expressions were checked under a fluorescence microscope (Zeiss Axio Observer Z.1) immediately after the mounting.

Table 1. Oligonucleotide sequences used for PCR analysis.

\begin{tabular}{llllll}
\hline Gene & Forwards $\left(5^{\prime} \rightarrow 3^{\prime}\right)$ & Reverse $\left(5^{\prime} \rightarrow 3^{\prime}\right)$ & $\begin{array}{c}\text { cDNA } \\
\text { Bp }\end{array}$ & $\begin{array}{c}\text { Tm } \\
{ }^{\circ} \mathrm{C}\end{array}$ & NCBI No. \\
\hline TUBB3 & GATAGGGGCCAAGTTCTGGGA & CTCTGGGCACATACTTGTGAGAGGA & 143 & 57 & XM_032887673.1 \\
CD34 & GCCATCTCAGAGACCACGGTC & GGTGGAGTGTTCACTTCTGGA & 156 & 57 & XM_032915361.1 \\
CD44 & GCATCCAACACCTCCCACTATGAC & CTGGTCCATCGAAGGAATTGGGTA & 106 & 57 & XM_032903796.1 \\
CD105 & GCGTCACACTTGAATGGCAACC & GGATGAGAACGGCATCCCCA & 180 & 58 & XM_032901802.1 \\
ITGB1 & TCCAGAAGGTGGCTTTGATGCA & CGTGGAAAACACCAGCAGTCG & 94 & 57 & XM_032888182.1 \\
NESTIN & AGGTGGCTACATACAGGACTCTGC CCCAAGGAAATTCGGCTTCAGC & 119 & 56 & XM_032898121.1 \\
ALCAM & TGAGGCACCTACCCTGGTC & TCTCCATCAACAGGCTGTAGCAC & 183 & 58 & XM_032900289.1 \\
NCAM & CACAAAGGCCGAGATGTCATCC & ACCTGAATGTCCTTGAAGTTGATCTC & 161 & 57 & XM_039080805.1 \\
GAPDH & GGCAAGTTCAACGGCACAGTC & GACGCCAGTAGACTCCACGAC & 144 & 58 & NM_017008.4 \\
\hline
\end{tabular}

cDNA: Complementary deoxyribonucleic acid, Bp: Base pairs, Tm: Melting temperature. 


\section{Results}

Isolation and Culture of Amniotic Membrane Derived Stem Cells: The cells started to proliferate on the plastic surface around 10 days after seeding the tissue samples (Figure 1A, B). The isolated cells at P0 were observed to possess epithelial and fibroblast-like morphologies (Figure 2 A). The epithelial morphology, however, started to diminish by passaging (Figure 2 B) and only the cells with fibroblast-like morphology were visible at further passages starting from P3 (Figure $2 \mathrm{C}, \mathrm{D}$, E, F).

Cell Proliferation and Colony Forming Ability: The crystal violet staining on $15^{\text {th }}$ day showed that the cells at $\mathrm{P} 0$ were able to form colonies when they were seeded at 1900 cells/well density in 4-well plates (Figure 1 C). To determine the doubling time, the cells were cultured up to the $10^{\text {th }}$ passage. In the context of doubling time, better results were obtained beginning from passage 5 and onward. The lowest doubling time was acquired from the $9^{\text {th }}$ passage which means that the maximum proliferation rate was shown in that passage within the shortest duration (Figure $3 \mathrm{~A}$ ). The viability of cells was higher than $96 \%$ after the $7^{\text {th }}$ passage till the $10^{\text {th }}$ passage (Figure $3 \mathrm{~B}$ ). In growth curve studies, graphics indicated that cells rapidly entered the logarithmic phase at passage 9 after 48 hours of lag phase. The lag phase continued until $10^{\text {th }}$ day whereas the cells showed an exponential growth after $6^{\text {th }}$ day. But the proliferation rates of P5 cells were found to be lower in growth curve studies (Figure $3 \mathrm{C}$ ).
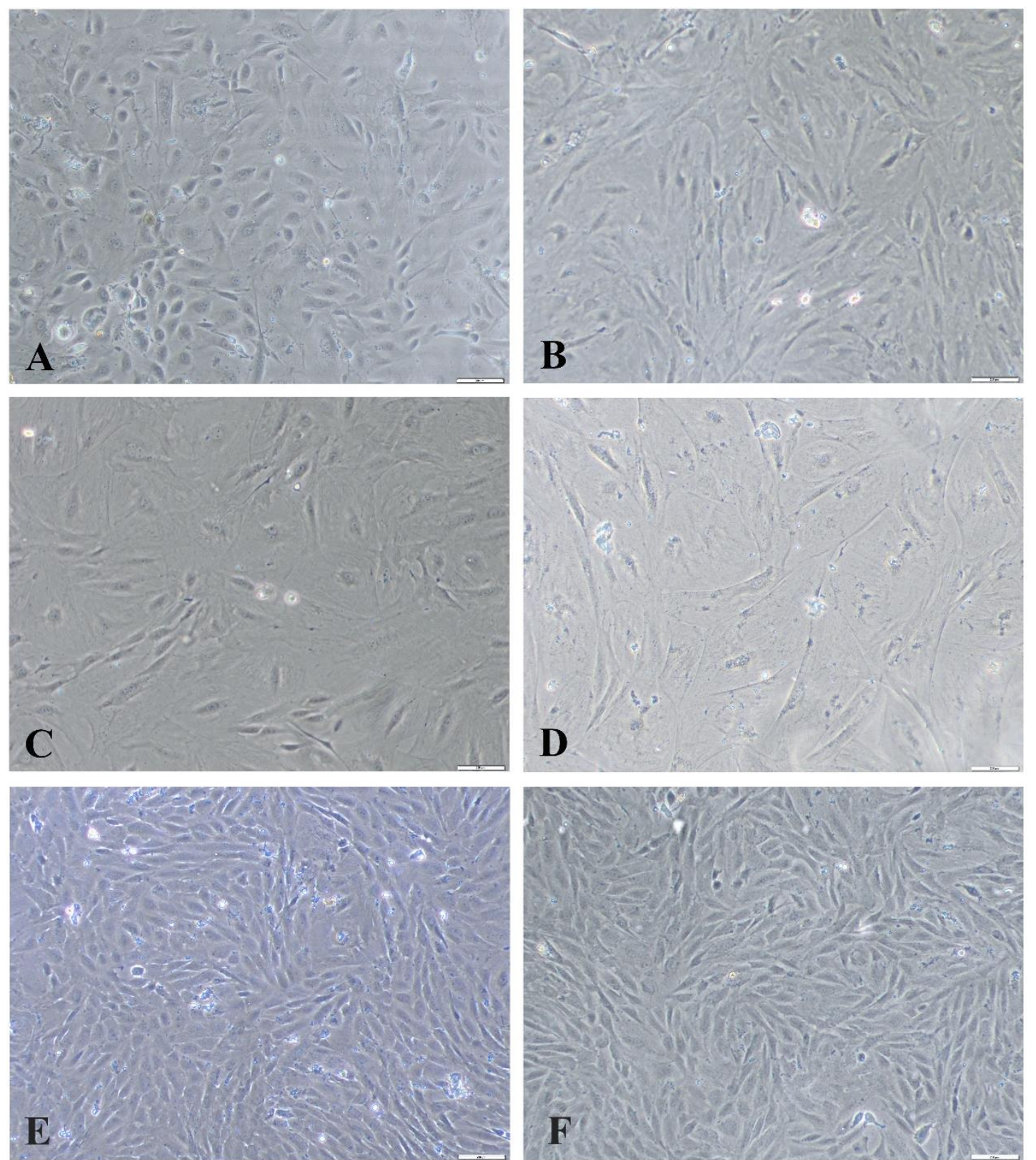

Figure 2. Fibroblast-like morphology of the cells started to be more intense after passage 1. (A: P0, B: P1, C: P3, D: P5, E: P7, F: P9). Bar $=200 \mu \mathrm{m}$. 

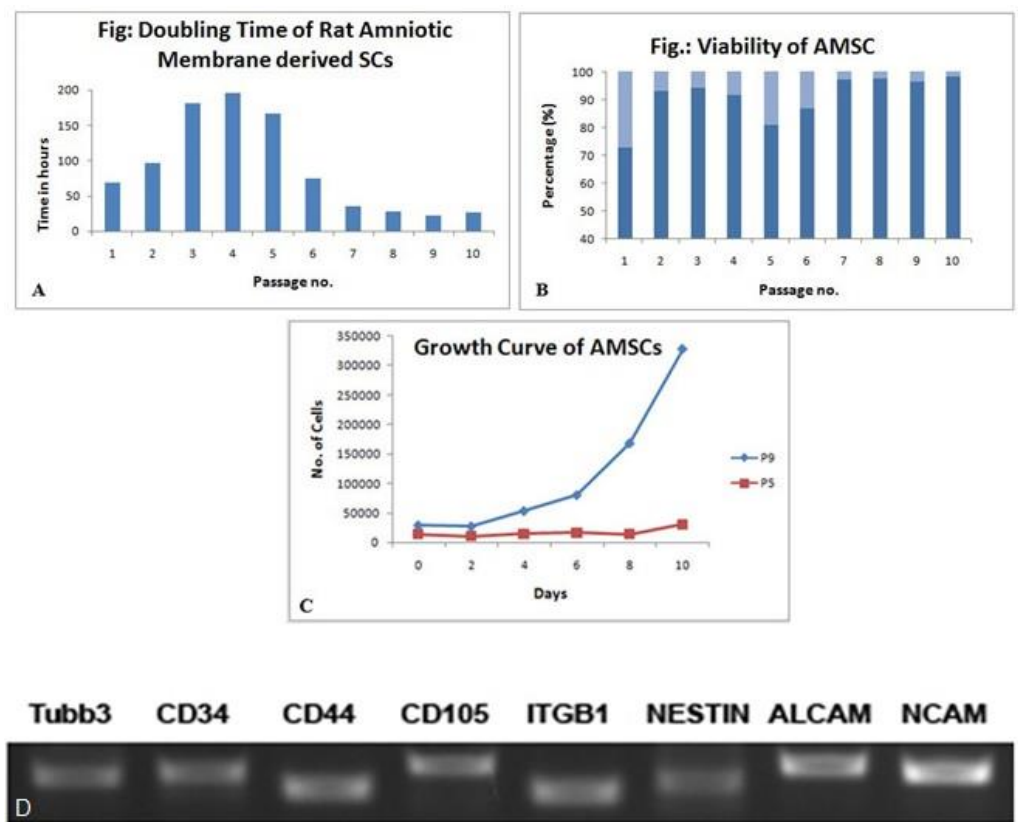

Figure 3. A: Doubling time graph for AMSCs. B: Cell viability graph for AMSCs.C: The growth curve analysis for P5 and P9 cells. D: PCR analysis of mesenchymal, neurogenic and, hematopoietic gene expressions on AMSCs.
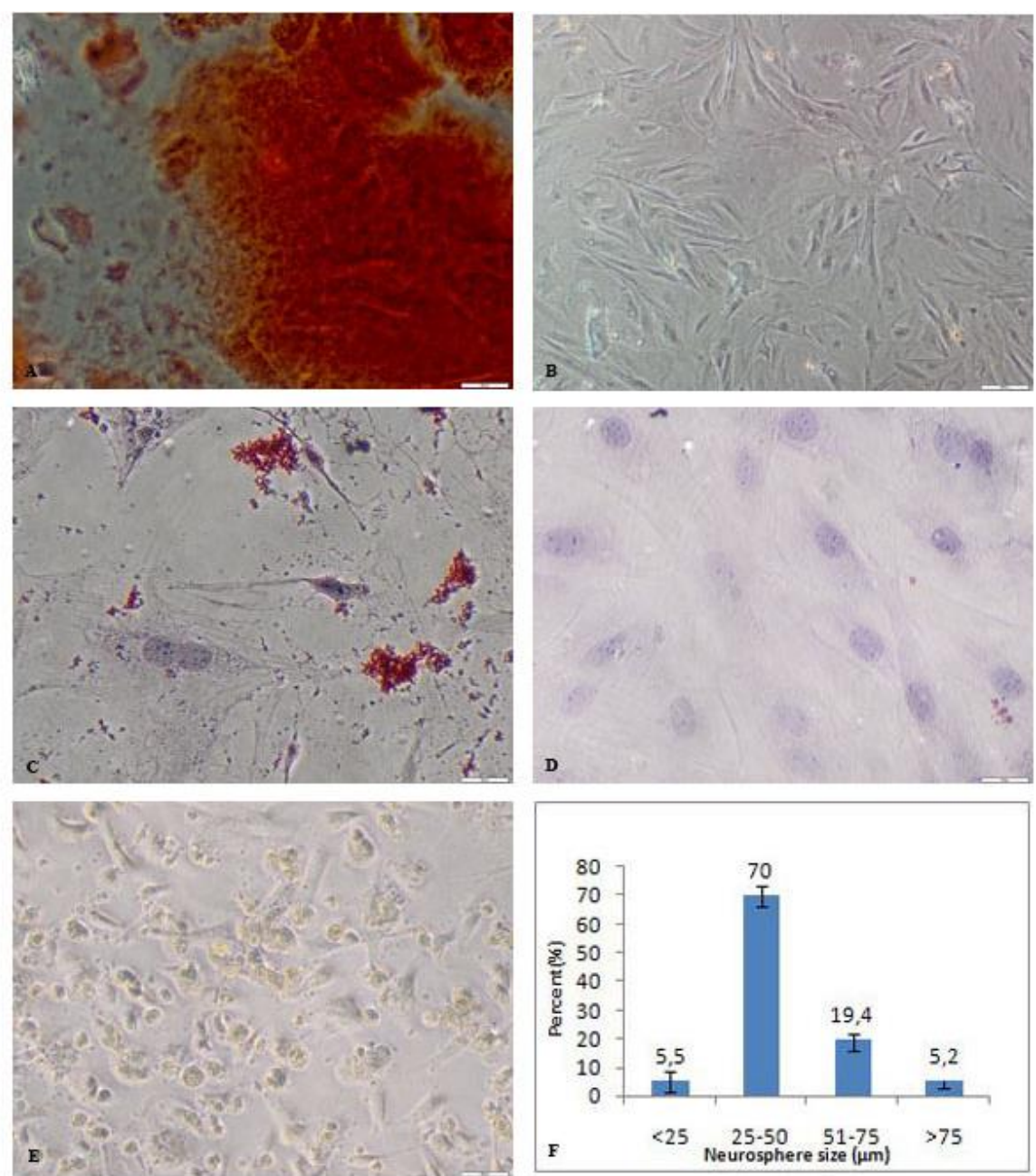

Figure 4. A, B: Alizarin red S staining. A: Osteogenic differentiation in AMSC's. Red color indicates positive staining for the calcium deposition of differentiated cells. Bar $=100 \mu \mathrm{m}$. B: No staining was visible in control group. Bar $=200 \mu \mathrm{m}$. C, D: Oil Red-O staining; counter stained with hematoxylin. C: Adipogenic differentiation in AMSC's. Red color indicates positive staining for the lipid vacuoles. Bar $=50 \mu \mathrm{m}$. D: No staining was visible in control group. Bar $=50 \mu \mathrm{m}$. E: Neurospheres at $48^{\text {th }}$ hour. Bar $=100 \mu \mathrm{m}$. F: Percentage distribution of the sizes of neurospheres. 
Gene Expression Patterns of AMSCs: A PCR analysis was performed to investigate various genes including mesenchymal stem cell markers [CD44, CD105, CD29 (ITGBI), CD166 (ALCAM)] alongside neurogenic cell markers [Nestin, NCAM, TUBB3 ( $\beta$-III tubulin)] and hematopoietic marker (CD34) on AMSCs (Figure 3 D). All the aforementioned genes were given positive results for our study.

Differentiation Studies: Amniotic stem cells were differentiated into osteogenic, adipogenic, and neurogenic lineages. Osteogenic differentiation was demonstrated with alizarin red S staining. In differentiation groups, redorange stained extracellular calcium deposits were shown as there was no staining in the negative control group and the morphology of those cells remained in an undifferentiated state (Figure 4 A, B). Adipogenic differentiation was confirmed by oil red $\mathrm{O}$ staining. Bright red stained cytoplasmic lipid vacuoles were demonstrated in the differentiation groups (Figure $4 \mathrm{C}$ ). While the morphology of differentiated cells was seen under microscopic evaluations, there were no morphological changes visible in the negative control and also there were no stained vacuoles visible in negative control wells (Figure 4 D). The cells were also subjected to neurogenic differentiation by neurosphere generation studies. For this purpose, cells were cultured with neurosphere induction medium for 48 hours. Neurospheres were started to be formed even at $24^{\text {th }}$ hour. After 48 hours of induction, free floating and round shaped neurospheres were found to be generated (Figure $4 \mathrm{E}$ ). At this point, sizes of the neurospheres were measured by using Image $\mathbf{J}$ software. It is found that $70 \%$ of the generated neurospheres had a radius of 25-50 microns whilst $19,4 \%$ of neurospheres were at a size of 51-75 microns (Figure $4 \mathrm{~F}$ ). There were also much smaller and bigger neurospheres, but the amount of those neurospheres were lesser. In order to confirm neural properties of the generated neurospheres, immunofluorescence staining was also performed at $48^{\text {th }}$ hour. Immunofluorescence staining against Nestin, $\beta$-III Tubulin and Sox 2 were all given positive results while there was no reaction at negative control wells as the staining demonstrated that the cells indeed possess neurogenic properties even after a short period of differentiation (Figure 5).

\section{DAPI}

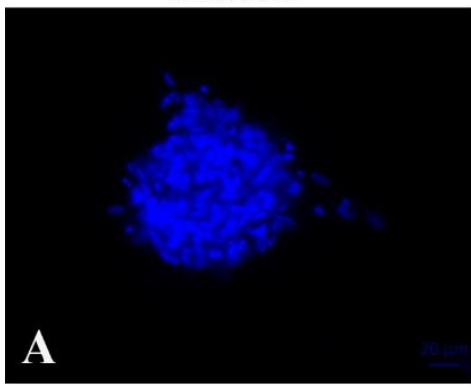

DAPI

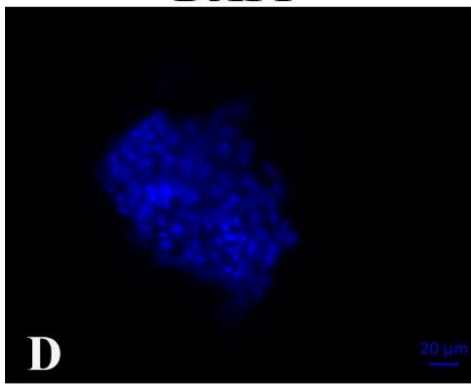

DAPI

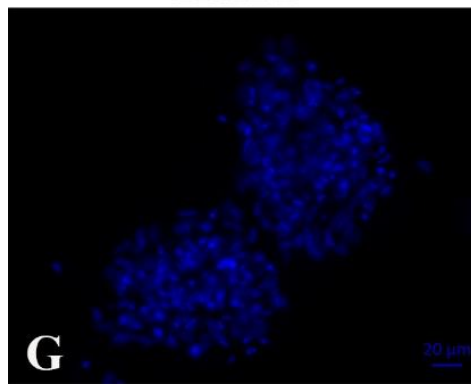

Sox2

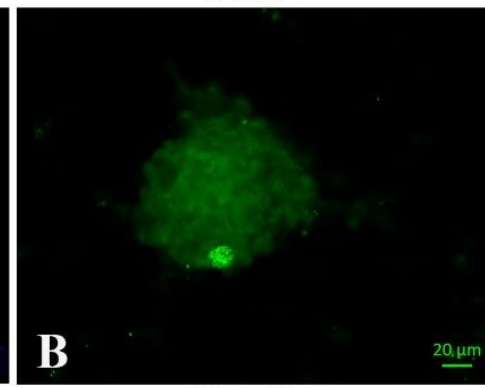

Nestin

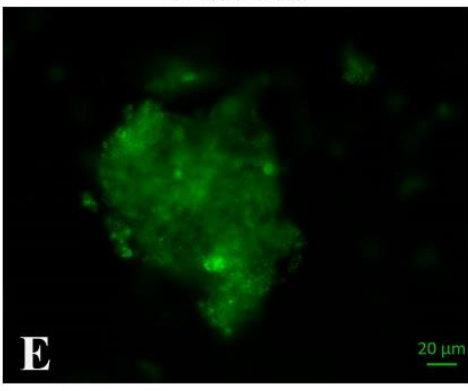

B-III Tubulin

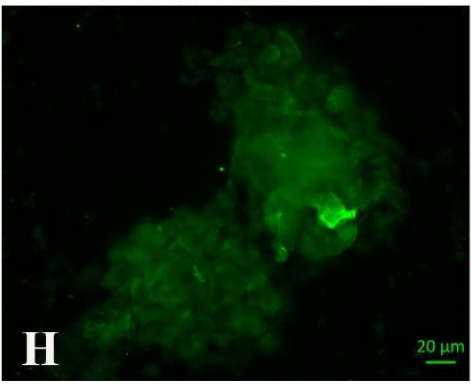

Merged

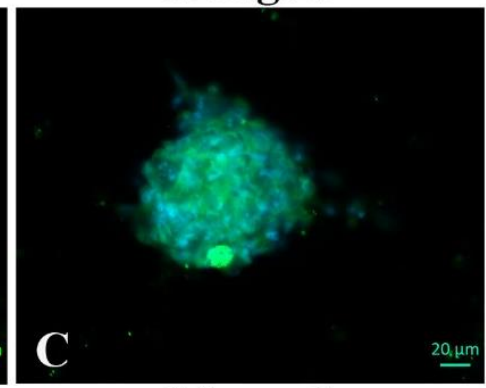

Merged

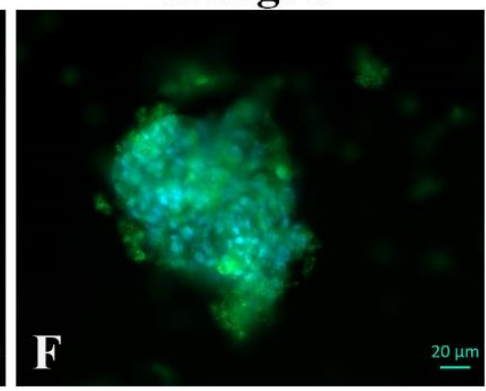

Merged

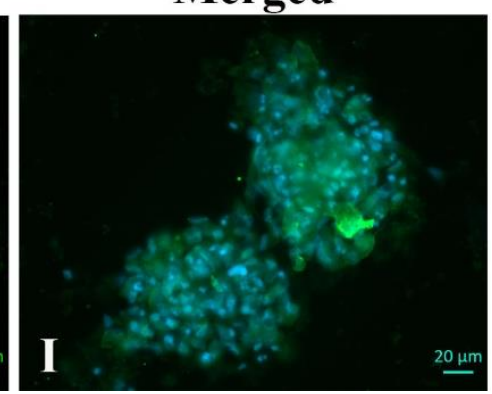

Figure 5. Immunofluorescence staining against Sox2, Nestin and B-III tubulin in neurospheres at 48 th hour. Nuclei stained with DAPI $(A, D, G)$. The results are pointing that neuropsheres are positive against Sox $2(B, C)$ and they have strong expression of neural progenitor marker Nestin (E, F) alongside with neurogenic marker $\beta$-III tubulin (H, I). Bar: $20 \mu \mathrm{m}$. 


\section{Discussion and Conclusion}

AMSCs were isolated in line with previous studies (25). Isolated AMSCs possess fibroblast-like morphology (Figure 2) with good adhesion potential similar to other studies $(10,11,19,25)$. In primarily cultured P0 cells, the cells usually have a heterogeneous population, consisting of fibroblast-like and/or round shaped morphologies (34). After the first passage, cells with fibroblast-like morphology began to increase (17). Similarly, cells of different morphologies were observed at P0 while fibroblast-like cells were observed to intensify in the following passages (Figure 2) in this study. In stem cell research, cells from passage 3 or further are usually preferable for differentiation analysis since both the uniform morphology generally commences and the cells express necessary stem cell markers from $\mathrm{P} 3$ and onwards $(18,20)$. Stem cells are supposed to be capable of forming colonies. In this study, it was observed that amniotic cells indeed formed colonies proving that they have the potential to colonize in the primary culture at P0. This situation may indicate a paracrine signalization among the cells as it has been reported in umbilical cord perivascular cells (36).

AMSCs were announced to have the capacity to differentiate into osteocytes and adipocytes $(25,27)$. Our findings from osteogenic and adipogenic differentiation studies match with previously reported researches.

The doubling time graph shows that after the $5^{\text {th }}$ passage, the proliferation rate increased and the doubling time remained very short till the $10^{\text {th }}$ passage (Figure $3 \mathrm{~A}$ ). Proliferation assays indicated that AMSCs were seen to reach the highest proliferation rate in the $9^{\text {th }}$ passage with the least doubling time (Figure $3 \mathrm{~A}$ ). Also, it has been shown that AMSCs had a viability ratio higher than $96 \%$ starting from passage 7 (Figure $3 \mathrm{~B}$ ). However, the previous reports indicate that doubling time begins to decrease with P3 $(18,19)$ and offer using stem cells from passage 3 for therapeutical approaches, as we observed that doubling time of our cells started reducing from passage 5 onward. Growth curve analysis was performed in passages 5 and 9 since the doubling time began to decrease by P5 and the shortest doubling time was measured in P9. In the context of growth curve, the analysis showed similarities with doubling time results. Cells represented a 48 hours of lag phase at passage 9. The cells showed a $\log$ phase continued until $10^{\text {th }}$ day afterwards. While the cells represented a long log phase with exponential growth at passage 9 ; passage 5 cells were found to be less proliferative (Figure $3 \mathrm{C}$ ). Those doubling time and growth curve analysis results pointed out that using AMSCs starting from passage 5 and following passages could be more proper for therapeutic approaches.

In this study, the expression of both mesenchymal (4, 18) and neurogenic (41) markers as well as hematopoietic
$(8,13)$ marker CD34 were observed by PCR analysis. Although a negative expression was expected for CD34 $(2,30)$, we detected mild expression for this gene which was similar to the findings of some previous studies $(8$, 13).

AMSCs are suitable for neurosphere formation because they express neuronal cell markers with mesenchymal cell markers. In this study, neurospheres were successfully generated from rat AMSCs as well as the other researches did in different species and/or different sources $(3,14,22,32)$. Neurospheres formed in vitro are a mixture of stem cells, progenitor cells, and further differentiated cells such as neuronal and glial cells $(7,23,39)$. A separation was also made depending on the sizes of the neurospheres. It was observed that a great portion of the neurospheres were small to medium in size with approximately 25-50 microns of diameters. Large neurospheres are the representatives of neuronal stem cells and they can be a good source of neurons. Furthermore, neurospheres with smaller size represent progenitor cells that can enhance and support the neurons as well as replenish nervous tissue by promoting glial cells (5). Neurospheres chosen by the means of those properties could be applied to an area of defect in neurogenic disorders (14). Neurospheres are anticipated to differentiate into neural cells since they are neural progenitor stem cells. Yet, a molecular neuroprogenitor characterization has to be done by checking related genes and proteins in order to prove neurogenic differentiation potentials of the neurospheres generated from AMSCs. To show the neuroprogenitor character of the generated neurospheres, we checked fluorescence expressions of some neural markers and demonstrated positive expressions for Nestin, Sox 2 and, $\beta$-III Tubulin after 48 hours of induction in the neurospheres generated from AMSCs. The results are consistent with previous neurospheres studies in that context $(22,28,32)$. Although there are many previous authors on the cells from different sources, neurosphere studies with amniotic membrane remain rare. Yan et al. (42), presented that neurospheres generated from human AMSCs express both Nestin and Sox2 similar to our study. They also conducted a comparative study between non-differentiated stem cells and neurospheres and stated that both relative expressions and positive cell percentages for Nestin and Sox 2 were significantly greater in neurosphere (42). Zhou et al. (44), also reported positive expression of Nestin in neurospheres at $3^{\text {rd }}$ day in their research on human AMSCs. They further differentiated neurospheres into neuron-like cells (NLC) and reported positive expressions for B-III tubulin, GFAP, S100 and MBP in those differentiated NLCs (44). In the study, although we did not perform NLC differentiation, we obtained positive results for B-III tubulin in neurospheres in a short notice like 48 
hours. Yet, most of the previous studies on neurospheres which were generated from AMSCs were conducted on humans and stem cells were isolated with enzymatic dissociation method $(42,44)$. We were unable to find any similar previous reports on neurospheres for both rat AMSCs generated neurospheres and amniotic membrane derived stem cells of any species which the isolation was made by explant culture method. These results may suggest that rat amniotic membrane derived stem cells are a promising source for neurosphere studies and explant culture method is a reliable method for neurosphere generation coupled with other previously reported advantages.

AMSCs isolated by explant culture proved to be a reliable stem cell type and to have high cell viability as well as their multilineage differentiation potential. Besides, neurospheres generated from AMSCs could be a potential candidate to be used on in vivo neural degeneration models.

\section{Acknowledgements}

We would like to acknowledge Mr. Tayfun Dikmen for his contributions in editing this article. A part of this study was presented in 3rd International Vetistanbul Group Congress, May 17-20 2016, Sarajevo, Bosnia and Herzegovina.

\section{Financial Support}

This work was supported by Afyon Kocatepe University, Scientific Research Projects Coordination Unit (16.KARIYER.23), Afyonkarahisar, Turkey.

\section{Ethical Statement}

This study was approved by the Afyon Kocatepe University Animal Experiments Local Ethics Committee (AKÜHADYEK-29-16; 17.03.2016).

\section{Conflict of Interest}

The authors declared that there is no conflict of interest.

\section{References}

1. Altunbaş K, Yaprakçı MV, Çelik S (2016): Isolation and characterization of olfactory stem cells from canine olfactory mисоsa. Kafkas Univ Vet Fak Derg, 22, 237-243.

2. Alviano F, Fossati V, Marchionni, et al (2007): Term amniotic membrane is a high throughput source for multipotent mesenchymal stem cells with the ability to differentiate into endothelial cells in vitro. BMC Dev Biol, 7, 11 .

3. Amendola D, Nardella M, Guglielmi L, et al (2014): Human placenta-derived neurospheres are susceptible to transformation after extensive in vitro expansion. Stem Cell Res Ther, 5, 55.
4. Asl KD, Shafaei H, Rad JS, et al (2017): Comparison of characteristics of human amniotic membrane and human adipose tissue derived mesenchymal stem cells. World $\mathrm{J}$ Plast Surg, 6, 33.

5. Azari H, Louis SA, Sharififar S, et al (2011): Neuralcolony forming cell assay: an assay to discriminate bona fide neural stem cells from neural progenitor cells. J Vis Exp, 49, e2639.

6. Azedi F, Kazemnejad S, Zarnani AH, et al (2017): Comparative capability of menstrual blood versus bone marrow derived stem cells in neural differentiation. Mol Biol Rep, 44, 169-182.

7. Bez A, Corsini E, Curti D, et al (2003): Neurosphere and neurosphere-forming cells: morphological and ultrastructural characterization. Brain Research, 993, 1829.

8. Cardoso MT, Pinheiro AO, Vidane AS, et al (2017): Characterization of teratogenic potential and gene expression in canine and feline amniotic membrane-derived stem cells. Reprod Domes Anim, 52, 58-64.

9. Chung CS, Fujita N, Kawahara N, et al (2013): $A$ comparison of neurosphere differentiation potential of canine bone marrow-derived mesenchymal stem cells and adipose-derived mesenchymal stem cells. J Vet Med Sci, 75, 879-886.

10. Corradetti B, Meucci A, Bizzaro D, et al (2013): Mesenchymal stem cells from amnion and amniotic fluid in the bovine. Reproduction, 145, 391-400.

11. Cremonesi F, Corradetti B, Consiglio AL (2011): Fetal adnexa derived stem cells from domestic animal: progress and perspectives. Theriogenology, 75, 1400-1415.

12. Díaz-Prado S, Muiños-López E, Hermida-Gómez T, et al (2010): Isolation and characterization of mesenchymal stem cells from human amniotic membrane. Tissue Eng Part C: Methods, 17, 49-59.

13. Fukuchi Y, Nakajima H, Sugiyama D, et al (2004): Human placenta-derived cells have mesenchymal stem/progenitor cell potential. Stem Cells, 22, 649-658.

14. Girard SD, Devéze A, Nivet E, et al (2011): Isolating nasal olfactory stem cells from rodents or humans. J Vis Exp, 54, e2762.

15. Jing W, Xiao J, Xiong Z, et al (2011): Explant culture: an efficient method to isolate adipose-derived stromal cells for tissue engineering. Artif Organs, 35, 105-112.

16. Kalendar R, Lee D, Schulman AH (2009): FastPCR software for PCR primer and probe design and repeat search. G3, 3, 1-14.

17. Kim J, Lee Y, Kim H, et al (2007): Human amniotic fluidderived stem cells have characteristics of multipotent stem cells. Cell Prolif, 40, 75-90.

18. Lange-Consiglio A, Corradetti B, Bizzaro D, et al (2012): Characterization and potential applications of progenitorlike cells isolated from horse amniotic membrane. J Tissue Eng Regen Med, 6, 622-635.

19. Lange-Consiglio A, Corradetti B, Meucci A, et al (2013): Characteristics of equine mesenchymal stem cells derived from amnion and bone marrow: in vitro proliferative and multilineage potential assessment. Equine Vet J, 45, 737744.

20. Lange-Consiglio A, Corradetti B, Bertani S, et al (2015): Peculiarity of porcine amniotic membrane and its derived 
cells: a contribution to the study of cell therapy from a large animal model. Cell Reprogram, 17, 472-483.

21. Lapchak PA (2015): A cost-effective rabbit embolic stroke bioassay: insight into the development of acute ischemic stroke therapy. Transl Stroke Res, 6, 99-103.

22. Li H, Yu S, Hao F, et al (2018): Insulin-like growth factor binding protein 4 inhibits proliferation of bone marrow mesenchymal stem cells and enhances growth of neurospheres derived from the stem cells. Cell Biochem Funct, 36, 331-341.

23. Lobo MV, Alonso FJM, Redondo C, et al (2003): Cellular characterization of epidermal growth factor-expanded freefloating neurospheres. J Histochem Cytochem, 51, 89-103.

24. Magatti M, Vertua $\mathbf{E}$, Cargnoni A, et al (2018): The immunomodulatory properties of amniotic cells: the two sides of the coin. Cell Transplant, 27, 31-44.

25. Marcus AJ, Coyne TM, Rauch J, et al (2008): Isolation, characterization, and differentiation of stem cells derived from the rat amniotic membrane. Differentiation, 76, 130144.

26. Mihu CM, Rus-Ciuca D, Soritau O, et al (2009): Isolation and characterization of mesenchymal stem cells from the amniotic membrane. Rom J Morphol Embryol, 50, 73-77.

27. Nawaz S, Özden Akkaya Ö, Dikmen T, et al (2020): Molecular characterization of bovine amniotic fluid derived stem cells with an underlying focus on their comparative neuronal potential at different passages. Ann Anat, 228, 151452.

28. Özden-Akkaya Ö, Dikmen T, Nawaz S (2019): Investigation of Sox $2, \beta$-III tubulinand nestin expressions in neuropsheres differentiated from bovine adipose derived mesenchymal stem cells by immunofluorescence staining. Kocatepe Vet J, 12, 336-342.

29. Pirjali T, Azarpira N, Ayatollahi M, et al (2013): Isolation and characterization of human mesenchymal stem cells derived from human umbilical cord Wharton's jelly and amniotic membrane. Int J Organ Transplant Med, 4, 111-116.

30. Portmann-Lanz CB, Schoeberlein A, Huber A, et al (2006): Placental mesenchymal stem cells as potential autologous graft for pre-and perinatal neuroregeneration. Am J Obstet Gynecol, 194, 664-673.

31. Reynolds BA, Weiss S (1992): Generation of neurons and astrocytes from isolated cells of the adult mammalian central nervous system. Science, 255, 1707-1710.

32. Rezaei F, Tiraihi T, Abdanipour A, et al (2018): Immunocytochemical analysis of valproic acid induced histone $\mathrm{H} 3$ and $\mathrm{H} 4$ acetylation during differentiation of rat adipose derived stem cells into neuron-like cells. Biotech \& Histochem, 93, 589-600.

33. Roth V (2006): Doubling Time Computing, Available from: http://www.doubling-time.com/compute.php. (Accessed Nov 11, 2020).

34. Rutigliano L, Corradetti B, Valentini L, et al (2013): Molecular characterization and in vitro differentiation of feline progenitor-like amniotic epithelial cells. Stem Cell Res Ther, 4, 133.

35. Salehinejad P, Alitheen NB, Ali AM, et al (2012): Comparison of different methods for the isolation of mesenchymal stem cells from human umbilical cord Wharton's jelly. In Vitro Cell Dev Biol Anim, 48, 75-83.

36. Sarugaser R, Lickorish D, Baksh D, et al (2005): Human umbilical cord perivascular (HUCPV) cells: a source of mesenchymal progenitors. Stem Cells, 23, 220-229.

37. Seo MS, Park SB, Kim HS, et al (2013): Isolation and characterization of equine amniotic membrane-derived mesenchymal stem cells. J Vet Sci, 14, 151-159.

38. Sun J, Wei ZZ, Gu X, et al (2015): Intranasal delivery of hypoxia-preconditioned bone marrow-derived mesenchymal stem cells enhanced regenerative effects after intracerebral hemorrhagic stroke in mice. Exp Neurol, 272, 78-87.

39. Suslov ON, Kukekov VG, Ignatova TN, et al (2002): Neural stem cell heterogeneity demonstrated by molecular phenotyping of clonal neurospheres. PNAS, 99, 1450614511.

40. Tang Y, Zhang C, Wang J, et al (2015): MRI/SPECT/fluorescent tri-modal probe for evaluating the homing and therapeutic efficacy of transplanted mesenchymal stem cells in a rat ischemic stroke model. Adv Funct Mater, 25, 1024-1034.

41. Woodbury D, Marcus AJ (2015): Obtaining multipotent amnion-derived stem cell (ADSC) from amniotic membrane tissue without enzymatic digestion. Google Patents.

42. Yan ZJ, Zhang P, Hu YQ, et al (2013): Neural stem-like cells derived from human amnion tissue are effective in treating traumatic brain injury in rat. Neurochem Res, $\mathbf{3 8}$, 1022-1033.

43. Yoon JH, Roh EY, Shin S, et al (2013): Comparison of explant-derived and enzymatic digestion-derived MSCs and the growth factors from Wharton's jelly. Bio Med Res Int, 2013, $\mathbf{4 2 8 7 2 6}$.

44. Zhou HL, Zhang XJ, Zhang MY, et al (2016): Transplantation of human amniotic mesenchymal stem cells promotes functional recovery in a rat model of traumatic spinal cord injury. Neurochem Res, 41, 2708-2718. 